\title{
SIMULATION OF NON-STATIONARY OBJECT CONTROL SYSTEM WITH CONSTANT SETTINGS IN THE SOFTWARE ENVIRONMENT Simulink
}

\author{
M.N. Erypalova, erymarya@yandex.ru \\ Perm National Research Polytechnic University, Berezniki Branch, \\ Berezniki, Russian Federation
}

\begin{abstract}
The sponge titanium production technology process is considered. Its control problems are considered. The positional control system of sponge titanium vacuum separation is investigated by simulation in the software environment Simulink (MATLAB). The process control capabilities with two standard types of controllers (position and PI) are considered. The optimal parameters of the position controller are selected using tabular method in MS Excel. The optimal parameters of the PI-controller are selected in the software environment Simulink (MATLAB). The transients are obtained with position and PI-controller. The impossibility of standard control methods using to this task has proved. The necessity to use more sophisticated methods of control to improve the quality of control has proved.

Keywords: non-stationary control object, sponge titanium vacuum separation, temperature twoposition control, self-oscillations, simulation.
\end{abstract}

The sponge titanium is purified from impurities - of magnesium and magnesium chloride - in a vacuum separation apparatus, which consists of a reactor and a capacitor. The impurities evaporate most intensively at the beginning of the separation, and the thermal power is maximal at this stage of the process. The impurities evaporation rate reduces during the process. The heat consumption is also reduced gradually and becomes the minimum after evaporation basic impurities of the reaction mixture. The distillation final stage of the remaining impurities (about $2 \%$ of the total) takes place almost at the minimum and constant consumption of thermal power [1].

The vacuum separation apparatus has three or more heating zones in which the temperature is maintained by two-position controllers. The actuators are heaters contactors, which have only two positions (on-off). The operating modes of separation temperature two-position control are self-oscillation processes.

The apparatus is a non-stationary control object. Therefore, heating zone temperature control twoposition system of apparatus operates in transient modes, which are characterized by self-oscillation complex shape with varying parameters. Dynamics of the separation apparatus heating zones is described in the first-order differential equations with variable coefficients. Each of the heating zones is considered on interval identification (during the period of self-oscillations) as a first-order quasistationary object with self-leveling or without. It is assumed that heating zones dynamic properties remains as a constant on the all identification interval. It is also assumed that the dynamic properties of the heating zones on the identification interval (gains, time constants, delay, perturbation actions) are known as a result of previously conducted identification by solving the algebraic system of equations describes temperature control self-oscillatory modes.

Even a slight increase of separation temperature leads to increase a speed of the process. Thus, to achieve the same magnesium removal completeness at $925^{\circ} \mathrm{C}$ at half the time is required than at $900{ }^{\circ} \mathrm{C}$ [1]. The separation speed increases over 100 times when process temperature is increased from 700 to $1000{ }^{\circ} \mathrm{C}$. But the separation temperature should not exceed $1085^{\circ} \mathrm{C}$ because at this temperature fusible eutectic "iron-titanium" is formed on the foundering wall of the reactor and depressurization system. In practice, for the maximum allowable temperature of the separation take $1050{ }^{\circ} \mathrm{C}$. The optimal positional control system is developed to intensify the separation process. This system enhances the separation temperature within acceptable limits by improving the quality of control [2]. The heating lower zone is considered as a control object.

We investigated the positional control system of sponge titanium vacuum separation by simulation in Simulink. 
Qualitatively, the position control system of the apparatus heating lower zone can be represented as follows (Fig. 1).

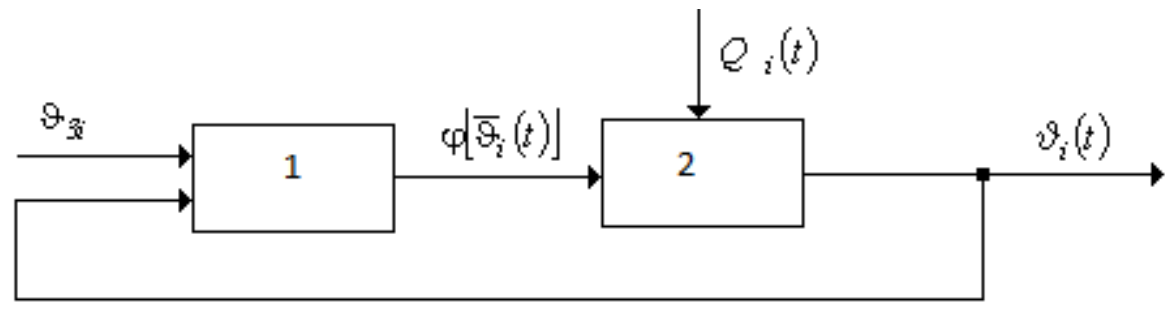

Fig. 1. The position control structure diagram of separation temperature

The heating lower zone (2) is regarded to the object of the first order with a self-leveling. It is transfer function in the form:

$$
W(s)=\frac{k_{\mathrm{o}} \cdot e^{-s \tau}}{T_{\mathrm{o}} s+1},
$$

where $k_{\mathrm{o}}$ - object gain, $e^{-s \tau}$ - delay, $T_{\mathrm{o}}$ - object time constant, $s$ - Laplace operator.

Variable disturbances acts on the object by the control channel - changing electric power consumption $Q_{i}(t)$, which characterizes the thermal power change of the separation process. The control object temperature is maintained at a predetermined level $\left(1020^{\circ} \mathrm{C}\right)$ by the multi-channel two-point controller with a dead zone equal to $4{ }^{\circ} \mathrm{C}$, using a microprocessor controller.

When the temperature exceeds the dead band upper limit $\left(1022^{\circ} \mathrm{C}\right)$, two-position controller turns off the heater zone; when the temperature drops below $1018^{\circ} \mathrm{C}$ (the lower limit of the dead zone) twoposition controller switch a heater on each. Heater power is equal to $130 \mathrm{~kW}$.

To divide the separation process into three stages (heating the reaction mass to a predetermined temperature; intensive distillation of the basic impurities; stripping small amount of remaining impurities) there is disturbance has been set using "Signal Builder" block (signal constructor) in Simulink. The "Signal Builder" block has a single output port. The output pulse is given in the form of which can be changed. The signal is adjusted in the form a changes graph of the thermal power through the stages of the process (Fig. 2).

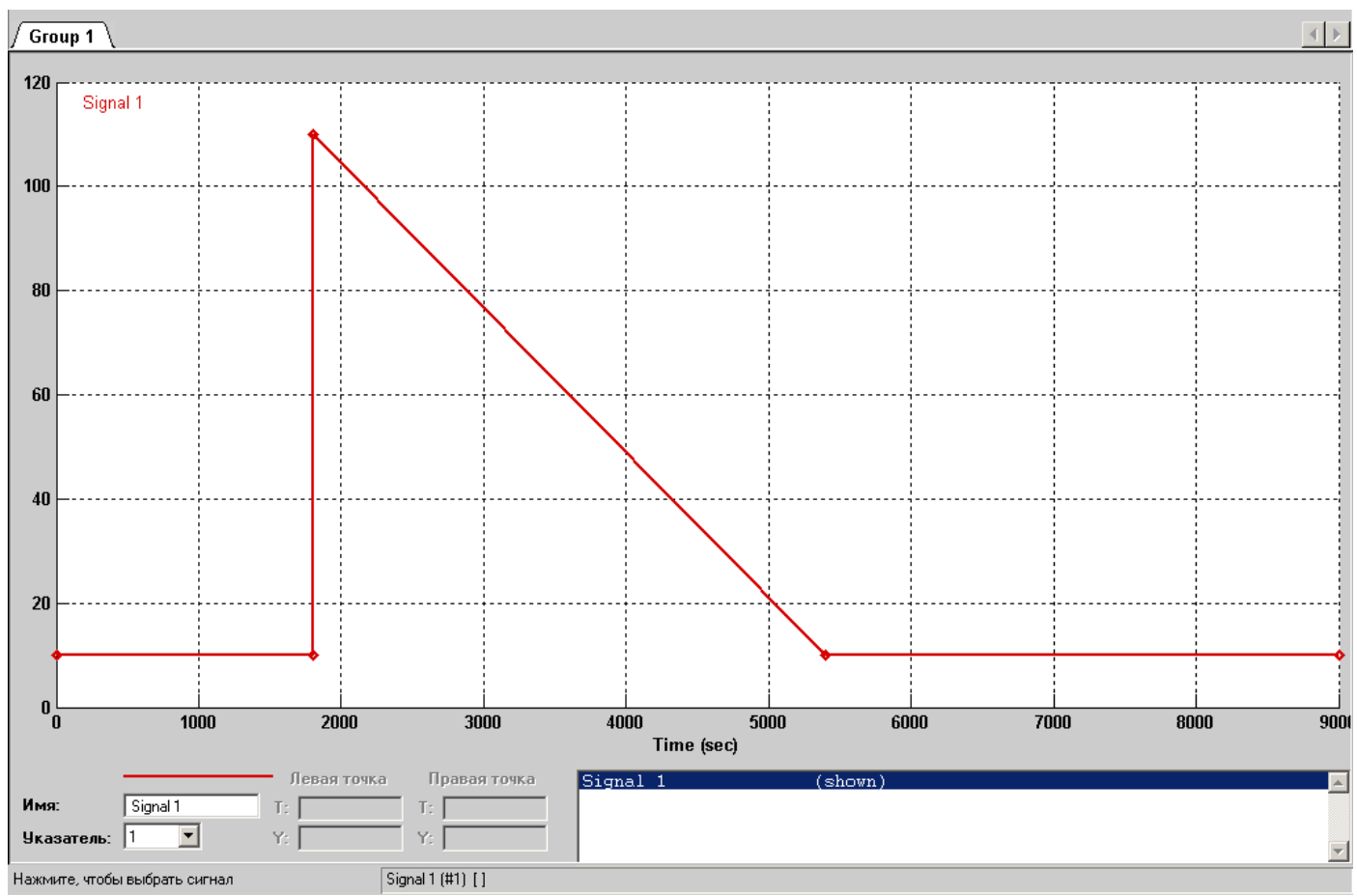

Fig. 2. The disturbance graph is modeled with the "Signal Builder" block for the three stages of the process 


\section{Краткие сообщения}

The permanent disturbance of $10 \mathrm{~kW}$ acts to the input of the object in the heating stage. The temperature control process is an established self-oscillation (Fig. 5).

Then the separation process begins, i.e. impurities intensive distillation stage, characterized by a sharp increase in thermal power up to $110 \mathrm{~kW}$.

Changing the thermal power in a step of intensive distillation (from 110 to $10 \mathrm{~kW}$ ) leads to the fact to follow. There is a transient mode of the temperature two-position control during the intensive distillation, a feature of which is to change the self-oscillation parameters: positive and negative amplitudes of the temperature deviation from the set value (set point); ON and OFF time of the heater zones. The heater on-time and amplitude of temperature negative deviations have their maximum values; the heater offtime and the amplitude of the temperature positive deviation - minimum values in the beginning of intensive distillation. Further, the two first parameter of oscillation gradually decrease, and two second parameter of oscillation increases.

The thermal power used for impurities evaporation is minimal and equal to $10 \mathrm{~kW}$ during the final stage. Then a steady-state mode of position controller work is set, where the self-oscillation parameters as constants, and the heater on-time and the amplitude of the negative deviation reaches its minimum value, and the time off the heater and the amplitude of the positive deviation - maximum values. and PI.

We considered the process control capabilities with two standard types of controllers: position

It should be noted that there is no theoretical methods to determine controllers optimal settings for objects with varying properties and delay. Therefore, selection of the optimal settings needs numerical optimization methods.

Object Model with position control is shown in Fig. 3. The control error has been implemented using "Abs" and "Integrator" blocks, so:

$$
R=\int_{0}^{t}\left|y(t)-y_{0}\right| d t
$$

where $y(t)$ - the output value of the object, $y_{0}$ - the set point, $t$ - the simulation time ( $\left.t \approx 9000 \mathrm{~s}\right)$. Setting parameters are dead band of the position controller $\Delta y$ and the heaters power (gain) $Q$ [1].

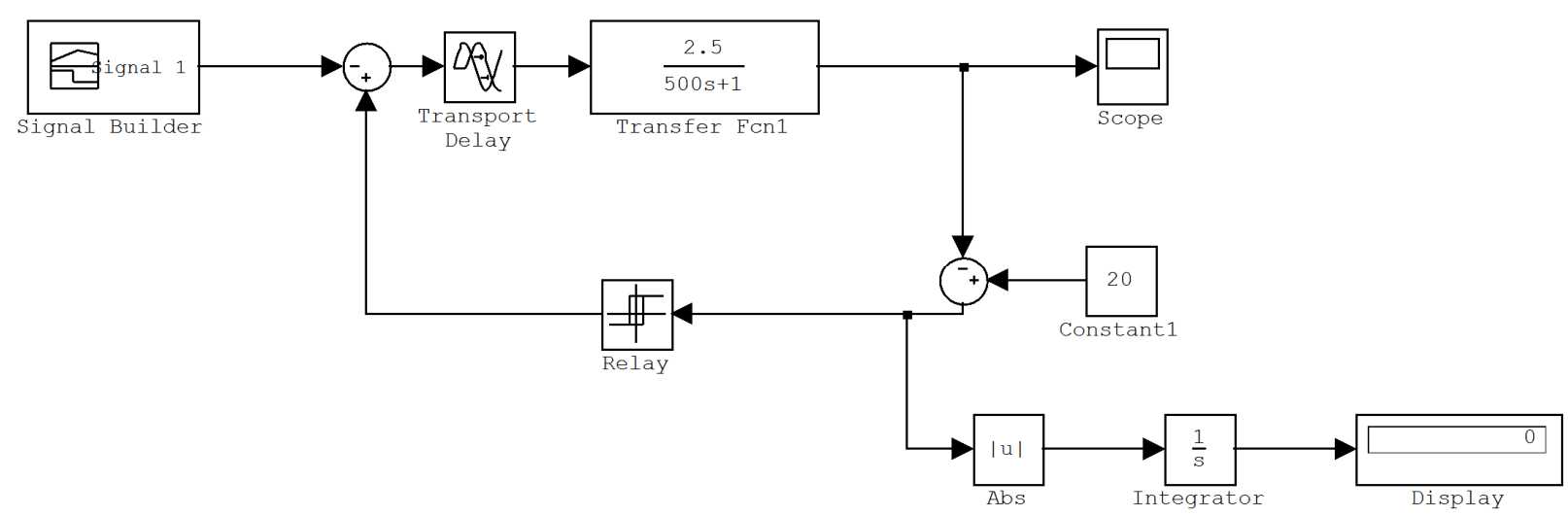

Fig. 3. The simulation model of the object with the position controller in Simulink application

The controller settings are selected with tabular method in MS Excel. As a result of revealed selection regardless of the $\Delta y$, optimum value $Q \approx 110 \mathrm{~kW}$ (Fig. 4). The simulation results are qualitatively consistent with the results of studies that had been previously obtained in the automated control system of the industrial vacuum separation apparatus $[3,4,5]$. At the same time, the existing technology uses heaters capacity of $130 \mathrm{~kW}$ in "AVISMA" branch of PJSC "VSMPO-AVISMA" Berezniki.

When we founded controller optimal settings, we are observed self-oscillations, which changes after the change of control object properties (Fig. 5, on the horizontal axis - the time in seconds, on the ordinate - the temperature rise of more than $1000^{\circ} \mathrm{C}$ ). 


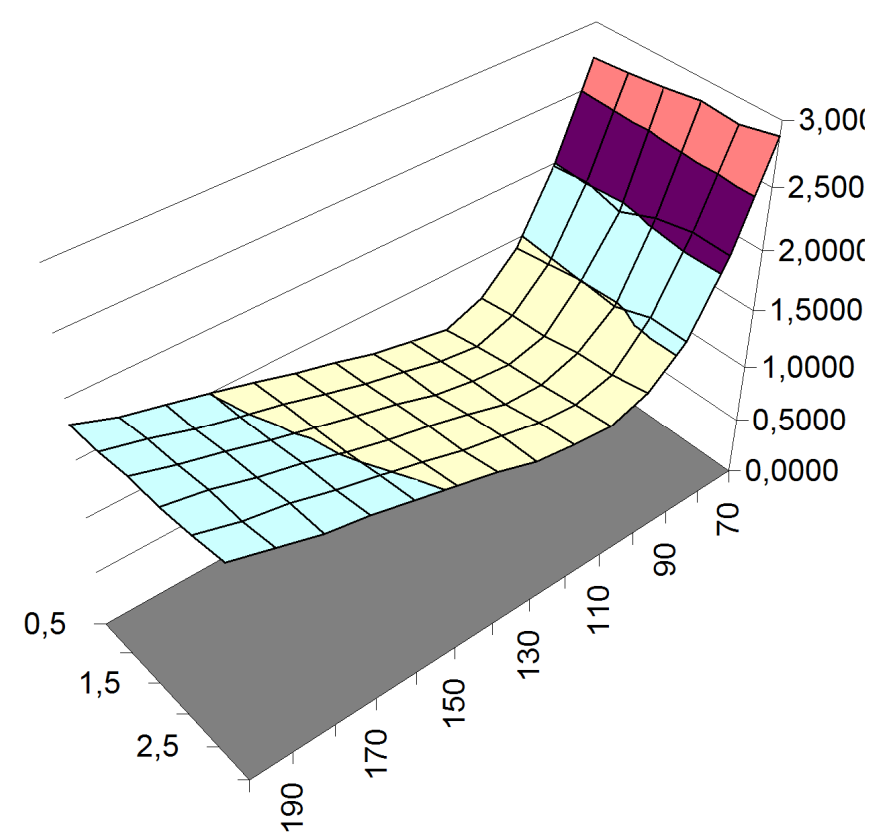

Fig. 4. The optimal parameters selection of the position controller using tabular method in MS Excel

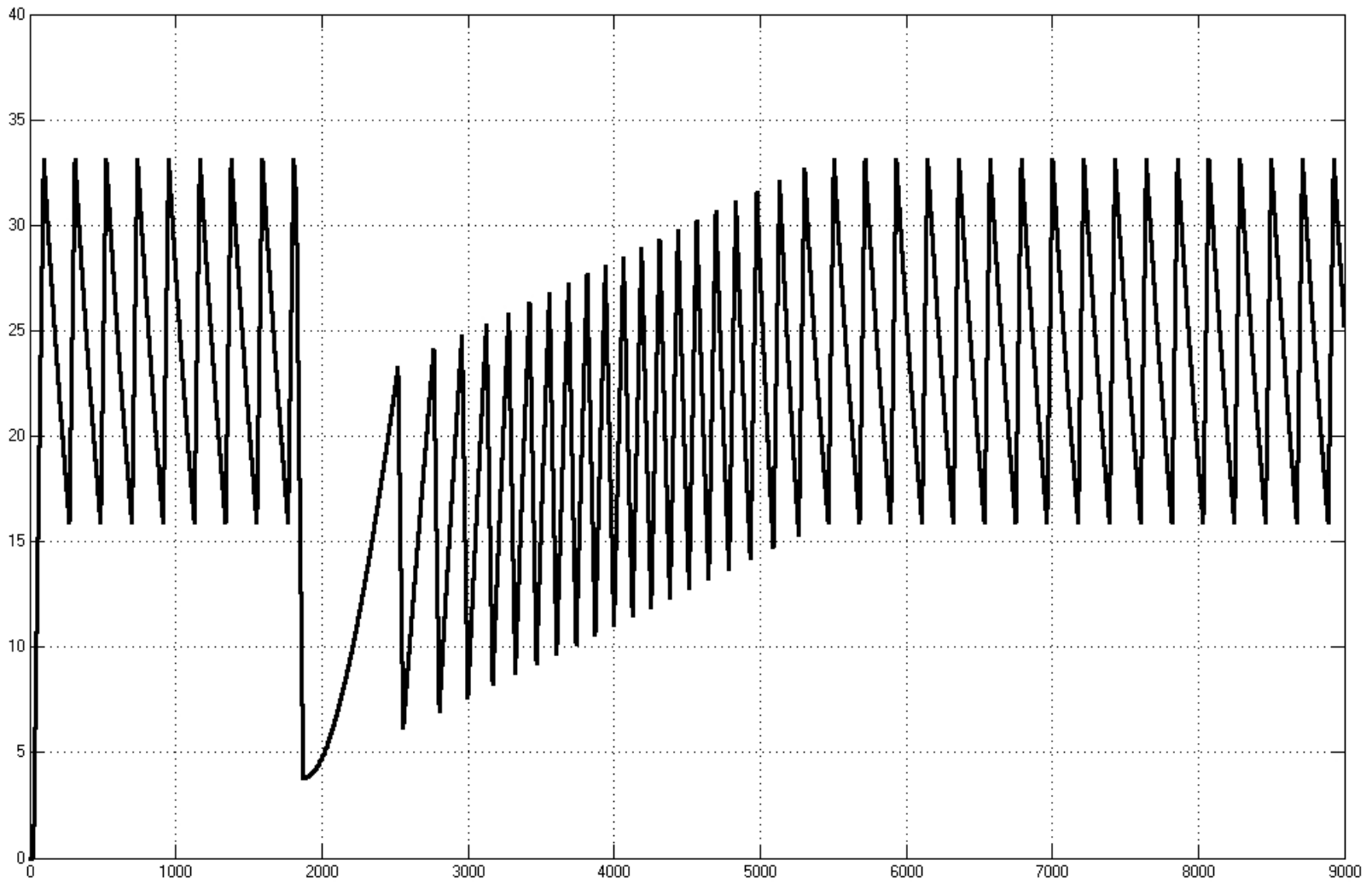

Fig. 5. The transient is obtained with the position controller

We try to realize a smooth change of furnace heater power. In this case, it is possible to use a standard PI-controller. Its settings are selected in the standard "PID Controller" block parameters, using the "Tune" function. Then we received transients which characterized by large regurgitation of values for the set point $\left(1020^{\circ} \mathrm{C}\right)$. It makes impossible using continuous controllers, because approach to $1085^{\circ} \mathrm{C}$ leads to an unacceptable increase of a probability of formation of low-melting eutectic "irontitanium" and fusion reactor wall (Fig. 6). 


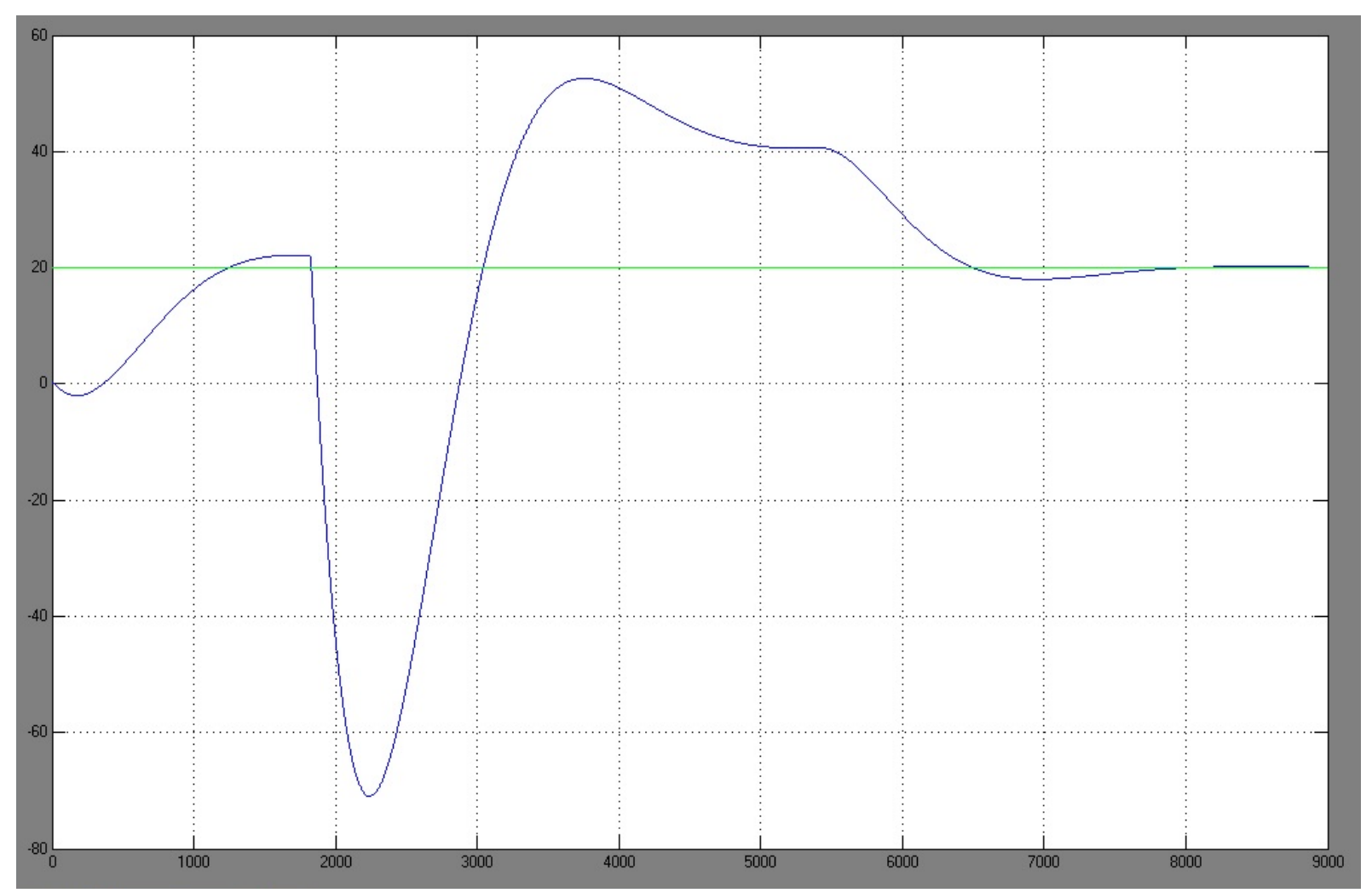

Fig. 6. The transient is obtained with PI-controller

The transition from the positional to continuous regulation is enough difficult with the existing equipment.

Thus, the study of two standard control methods in relation to the process of sponge titanium separation shown that it is necessary to use more sophisticated methods of control to improve the quality of control.

\section{References}

1. Erypalova M.N., Bekker V.F., Zatonskiy A.V. Upravlenie processom vakuumnoj separacii gubchatogo titana [The Process Control of Sponge Titanium Vacuum Separation]. LAP LAMBERT Academic Publishing GmbH \& Co. KG. Saarbruecken, 2011. 150 p.

2. Kirin Ju.P., Zatonskiy A.V., Bekker V.F., Bil'fel'd N.V. [Synthesis of Control Optimal Systems for Sponge Titanium Magnesium-Thermal Producing]. Automatisation. Modern Technologies, 2010, no. 9, pp. 18-21. (in Russ.)

3. Erypalova M.N., Bekker V.F., Zatonskiy A.V., Kirin Ju.P. [Influence of Control Object Unsteadiness on the Established Self-Oscillation Parameters]. News of Higher Educational Institutions. Volga region. Technical Science, 2008, no. 4, pp. 50-57. (in Russ.)

4. Kirin Ju.P., Zatonskiy A.V., Bekker V.F., Kraev S.L. [Identification of Technology Processes in Sponge Titanium Production]. Problem of control, 2008, no. 4, pp. 71-77. (in Russ.)

5. Bekker V.F., Erypalova M.N., Zatonskij A.V. [Modeling of Non-Stationary Sponge Titanium Separation Process]. Modern Science: Urgent Problems of the Theory and Practice. Series: Natural and Technical Science, 2013, no. 9-10, pp. 19-27. (in Russ.)

Received 28 November 2016 


\title{
МОДЕЛИРОВАНИЕ СИСТЕМЫ УПРАВЛЕНИЯ НЕСТАЦИОНАРНЫМ ОБЪЕКТОМ С ПОСТОЯННЫМИ НАСТРОЙКАМИ В ПРОГРАММНОЙ СРЕДЕ Simulink
}

\author{
М.Н. Ерыпалова \\ Пермский национальный исследовательский политехнический университет, \\ Березниковский фрилиал, г. Березники
}

Рассмотрены технологический процесс получения губчатого титана, возможные проблемы при построении системы управления этим процессом. Исследована позиционная система управления процессом вакуумной сепарации губчатого титана методом имитационного моделирования в программной среде Simulink (MATLAB). Рассмотрены возможности управления процессом при помощи двух стандартных видов регуляторов: двухпозиционного и ПИ-регулятора. Подобраны оптимальные настройки позиционного регулятора табличным методом с помощью MS Excel. Найдены оптимальные настройки ПИ-регулятора в программной среде Simulink (MATLAB). Получены переходные процессы для позиционного и ПИ-регулятора. Доказана невозможность качественного управления с применением стандартных схем автоматизации. Доказана необходимость использования более сложных методов регулирования для повышения качества процесса.

Ключевые слова: нестационарный объект управления, вакуумная сепарация губчатого титана, двухпозиционное управление температурой, автоколебания, имитационное моделирование.

\section{Литература}

1. Ерыпалова, М.Н. Управление прочессом вакуумной сепарации губчатого титана / M.H. Eрыпалова, В.Ф. Беккер, A.В. Затонский. - LAP LAMBERT Academic Publishing GmbH\&Co. KG. Saarbruecken, 2011. - $150 \mathrm{c}$.

2. Синтез и анализ оптимального позиционного управления технологическими процессами производства губчатого титана / Ю.П. Кирин, А.В. Затонский, В.Ф. Беккер, Н.В. Бильфельд // Автоматизация. Современные технологии. - 2010. - № 9. - С. 18-21.

3. Влияние нестационарности объекта управления на параметры установившихся автоколебаний/ М.Н. Ерыпалова, В.Ф. Беккер, А.В. Затонский, Ю.П. Кирин // Известия высших учебных заведений. Поволжский регион. Технические науки. - 2008. - № 4. - С. 50-57.

4. Идентификация технологических прочессов производства губчатого титана / Ю.П. Кирин, А.В. Затонский, В.Ф. Беккер, С.Л. Краев // Проблемы управления. - 2008. - № 4. - С. 71-77.

5. Беккер, В.Ф. Моделирование нестачионного проиесса сепарации губчатого титана / В.Ф. Беккер, М.Н. Ерыпалова, А.В. Затонский // Современная наука: актуальные проблемы теории и практики. Серия: Естественные и технические науки. - 2013. - № 9-10. - С. 19-27.

Ерыпалова Мария Николаевна, канд. техн. наук, доцент кафедры автоматизации технологических процессов, Пермский национальный исследовательский политехнический университет, Березниковский филиал, г. Березники; erymarya@yandex.ru.

Поступила в редакцию 28 ноября 2016 г.

\section{ОБРАЗЕЦ ЦИТИРОВАНИЯ}

Erypalova, M.N. Simulation of Non-Stationary Object Control System with Constant Settings in the Software Environment Simulink / M.N. Erypalova // Вестник ЮУрГУ. Серия «Компьютерные технологии, управление, радиоэлектроника». - 2017. - Т. 17, № 1. C. $134-139$. DOI: $10.14529 / \mathrm{ctcr} 170115$

\section{FOR CITATION}

Erypalova M.N. Simulation of Non-Stationary Object Control System with Constant Settings in the Software Environment Simulink. Bulletin of the South Ural State University. Ser. Computer Technologies, Automatic Control, Radio Electronics, 2017, vol. 17, no. 1, pp. 134-139. DOI: $10.14529 /$ ctcr170115 